\title{
Noncommunicable disease among adults with cerebral palsy
}

A matched cohort study

Jennifer M. Ryan, PhD, Mark D. Peterson, PhD, Anthony Matthews, MSc, Nicola Ryan, MB BCh BAO, Kimberley J. Smith, PhD, Neil E. O'Connell, PhD, Silvia Liverani, PhD, Nana Anokye, PhD,

Christina Victor, PhD, and Elizabeth Allen, PhD

Neurology ${ }^{\circledR}$ 2019;93:e1385-e1396. doi:10.1212/WNL.0000000000008199

\section{Abstract}

\section{Objective}

To compare the incidence of noncommunicable diseases between adults with and without cerebral palsy (CP).

\section{Methods}

A cohort study was conducted using primary care data from the Clinical Practice Research Datalink. Cox models, stratified by matched set and adjusted for potential confounders, were fitted to compare the risk of any noncommunicable disease, cancer, cardiovascular disease, type 2 diabetes mellitus, and respiratory disease between adults with and without CP.

\section{Results}

The analysis included 1,705 adults with CP and 5,115 age-, sex-, and general practice-matched adults without CP. There was evidence from adjusted analyses that adults with CP had $75 \%$ increased risk of developing any noncommunicable disease compared to adults without CP (hazard ratio [HR] 1.75, 95\% confidence interval [CI] 1.58-1.94). Specifically, they had increased risk of cardiovascular disease (HR 1.76, 95\% CI 1.48-2.11) and respiratory disease (HR 2.61, 95\% CI 2.14-3.19). There was no evidence of increased risk of cancer or type 2 diabetes mellitus.

\section{Conclusions}

Adults with CP had increased risk of noncommunicable disease, specifically cardiovascular and respiratory disease. These findings highlight the need for clinical vigilance regarding identification of noncommunicable disease in people with CP and further research into the etiology and management of noncommunicable disease in this population.
Correspondence

Dr. J.M. Ryan

jenniferryan@rcsi.com

\section{MORE ONLINE}

๑ CME Course

NPub.org/cmelist

From the Department of Epidemiology and Public Health Medicine (J.M.R.), Royal College of Surgeons in Ireland, Dublin; Institute of Environment, Health and Societies (J.M.R., N.E.O., N.A., C.V.), Brunel University London, UK; Department of Physical Medicine and Rehabilitation (M.D.P.), University of Michigan-Medicine, Ann Arbor; Departments of NonCommunicable Disease Epidemiology (A.M.) and Medical Statistics (E.A.), London School of Hygiene and Tropical Medicine; Department of Cardiology (N.R.), Aberdeen Royal Infirmary, UK; Department of Interventional Cardiology (N.R.), Hospital Clínico San Carlos, Madrid, Spain; Department of Psychological Sciences (K.J.S.), Faculty of Health and Medical Sciences, University of Surrey, Guildford; and School of Mathematical Sciences (S.L.), Queen Mary University of London, UK. 


\section{Glossary}

$\mathbf{B M I}=$ body mass index; $\mathbf{C I}=$ confidence interval; $\mathbf{C O P D}=$ chronic obstructive pulmonary disease $\mathbf{C P}=$ cerebral palsy; CPRD = Clinical Practice Research Datalink; GP = general practitioner; HR = hazard ratio; ID = intellectual disability; NCD = noncommunicable disease.

Cerebral palsy $(\mathrm{CP})$ is characterized by abnormal fine and gross motor functioning. ${ }^{1,2}$ People with $\mathrm{CP}$ may also experience comorbid conditions such as intellectual disability (ID), epilepsy, and visual and hearing impairment. ${ }^{1,3-5}$ While substantial improvements were observed in survival among children with CP between 1983 and 2010, survival among adolescents and adults with $\mathrm{CP}$ who are 15 to 60 years of age and feed orally and all adults with $\mathrm{CP}>60$ years of age did not improve at the same rate as survival in the general population. ${ }^{6}$ Several factors associated with $\mathrm{CP}$ may contribute to this widening gap in survival, including severity of motor impairments and presence of epilepsy, ID, musculoskeletal disorders, and mental health disorders. ${ }^{7-11}$ An elevated risk of noncommunicable disease (NCD) among people with $\mathrm{CP}$ may also explain this widening gap.

NCD, particularly cardiovascular disease, cancer, respiratory disease, and diabetes mellitus, is a leading cause of premature mortality worldwide. ${ }^{12}$ Physical inactivity, which is known to be prevalent among people with $\mathrm{CP},{ }^{13}$ is a shared and modifiable risk factor for these conditions. ${ }^{14,15}$ Evidence for the metabolic consequences of physical inactivity among people with spinal cord injury prompted comparison to people with $\mathrm{CP},{ }^{16}$ leading to the hypothesis that a negative cycle of physical inactivity, accelerated loss of muscle mass, reduced cardiorespiratory fitness, and worsening mobility contributes to elevated risk of NCD in people with $\mathrm{CP} .{ }^{17}$

While there is evidence that adults with $\mathrm{CP}$ have increased risk of NCD-related mortality, specifically mortality due to cardiovascular disease, respiratory disease, and cancer, compared to the general population, ${ }^{18-20}$ there is less evidence for the relative risk of NCD among adults with CP. In 2015, a crosssectional study identified that adults with $\mathrm{CP}$ in the United States had higher odds of cardiovascular and chronic respiratory disease, but not diabetes mellitus, compared to adults without $\mathrm{CP} .^{21}$ However, this study was limited by reliance on self-reported data, a potentially unrepresentative population of adults with $\mathrm{CP}$, and controls who were not matched to adults with CP. A second cross-sectional study conducted in the United States identified higher odds of cardiometabolic, but not pulmonary, morbidity among young adults with $\mathrm{CP}$ compared to adults without $\mathrm{CP} .{ }^{22}$ Because cardiometabolic morbidity was defined as the presence of one of a number of conditions, including hyperlipidemia, this study did not provide information on the risk of specific NCDs such as heart failure, ischemic heart disease, asthma, cancer, or diabetes mellitus among adults with CP. The only study to date to examine the risk of NCD among adults with
CP outside of the United States reported an increased risk of stroke among adults with $\mathrm{CP}$ in Taiwan. ${ }^{23}$ However, the authors did not explore the risk of other NCDs such as respiratory disease, diabetes mellitus, and cancer.

There is a widening gap in life expectancy between some adults with $\mathrm{CP}$ and the general population, which may be explained by an increased risk of NCD. While a higher risk of cardiovascular disease and chronic respiratory disease was identified among adults with $\mathrm{CP}$ in the United States, ${ }^{21}$ such a study exploring the risk of numerous NCDs has not been replicated outside of the United States. Furthermore, while there is evidence that adults with CP have a higher risk of mortality due to cancer, no study has examined the relative risk of cancer in adults with CP to date. This study aimed to compare the rate of NCDs, namely cardiovascular disease, chronic respiratory disease, cancer, and diabetes mellitus, between adults with and without $\mathrm{CP}$ in the United Kingdom.

\section{Methods}

\section{Study design and data source}

A matched cohort study was conducted using data from the UK Clinical Practice Research Datalink (CPRD). The CPRD contains primary care data routinely collected via electronic health records from general practices across all regions of the United Kingdom. The CPRD covers $\approx 7 \%$ of the UK population, and data are largely representative of the UK population in terms of age and sex. ${ }^{24,25}$ The CPRD includes data on clinical events, prescriptions, preventive care, referrals, hospital admissions, and lifestyle and anthropometric measures. Clinical diagnoses are recorded in general practices using the Read clinical classification system, which is a hierarchical system of recording clinical data. Read codes, consisting of letters and numbers, are recorded for each clinical diagnosis and are accompanied by Read terms, which are a corresponding written description of the condition. Data collection began in 1987, and we used data obtained during the period from January 1, 1987, to November 30, 2015.

\section{Participants}

Patients $\geq 18$ years of age with at least 1 record of CP occurring during the study period and research-standard follow-up (i.e., follow-up meeting criteria developed by the CRPD to determine whether data are of sufficient quality to be used in research) were included. A list of 23 Read codes, which included cerebral palsy, spastic cerebral palsy, and congenital cerebral palsy, was used to identify patients with CP. Start of follow-up (i.e., the index date) for patients with $\mathrm{CP}$ was the 
latest of the following: the date of registration with the general practice, the date data were considered research standard, or January 1 of the year in which the patient turned 18 years of age. Patients with a record of $\mathrm{CP}$ were matched to 3 control patients without $\mathrm{CP}$ on age (within 3 years in either direction), sex, and practice. Matching on practice controlled for practice-level socioeconomic status and between-practice variations in general practitioner (GP) diagnostic behaviors. The index date for control patients was set to the index date of their matched case. Control patients had a complete history for the duration of their case's follow-up.

\section{Outcomes}

We examined the incidence of cancer, cardiovascular disease, type 2 diabetes mellitus, and respiratory disease because these 4 NCDs account for $82 \%$ of NCD-related premature mortality. ${ }^{12}$ Cancer was identified as a first event of breast, colorectal, lung, or prostate cancer. Breast, colorectal, lung, and prostate cancer are consistently the most common cancer sites, accounting for $52.8 \%$ of cancer registrations in England in $2016 .{ }^{26}$ Cardiovascular disease was identified as a first event of heart failure, hypertensive disease, ischemic heart disease, cerebrovascular disease, or other heart disease. Respiratory disease was identified as a first event of chronic obstructive pulmonary disease (COPD) or asthma. Asthma was identified using a previously validated list of Read codes. ${ }^{27}$ For other diagnoses, when a validated list was not available, the Read code dictionary was searched to identify Read terms pertaining to all outcomes. Final code lists were reviewed by a consultant cardiologist.

In addition, the following criteria were applied to identify COPD and type 2 diabetes mellitus. A Read code for COPD, first recorded after the patient turned 35 years of age, was used to identify COPD. Diabetes mellitus was identified by (1) a code for a definite diabetes diagnosis, (2) a code for a possible diabetes diagnosis with a subsequent prescription for oral antidiabetics, or (3) $\geq 2$ diabetes drug prescriptions after the start of follow-up. These criteria have been used to identify diabetes mellitus sin a previous study using the CPRD. ${ }^{28}$ Because it is not always possible to distinguish between type 1 and type 2 diabetes mellitus from Read codes for diabetes mellitus and when the type of diabetes mellitus is stated this information may not be reliable, ${ }^{29}$ age at first diagnosis, age at first treatment, and treatment received were used to classify type of diabetes mellitus. ${ }^{28,30}$ Patients were identified as having type 2 diabetes mellitus if they were $>35$ years of age at the first diabetes diagnosis or they received exclusively oral antidiabetics after the age of 35 years.

\section{Covariates}

Smoking status (current smoker, ex-smoker, nonsmoker), alcohol consumption (current drinker, ex-drinker, or nondrinker), and body mass index (BMI) were identified. BMI was identified using values for height, weight, and BMI taken by the GP. ${ }^{31}$ When multiple records of BMI, smoking status, and alcohol consumption were available, the earliest record after the patient turned 18 years of age was used for the analyses. Although the record may have been taken before the start of research-standard follow-up, it was deemed preferable to include these data to maximize the available data. Records taken before research-standard follow-up were removed in a sensitivity analysis. We calculated the mean yearly GP consultation rate for each patient by dividing the total number of face-to-face or telephone consultations during follow-up by the total number of years of follow-up (i.e., start of follow-up to first event of any NCD or censoring).

\section{Statistical analysis}

For each outcome, patients were followed up to the earliest of the following: transfer out of CPRD, end of study period, practice last collection date, death, or first event of the outcome. Baseline characteristics of patients with and without CP were described.

In the primary analysis, a separate Cox model with an underlying age time scale, stratified by matched set, was fitted for each outcome (i.e., cancer, cardiovascular disease, type 2 diabetes mellitus, and respiratory disease). ${ }^{32}$ A stratified model assumes that patients in each strata have a different baseline hazard but that all other exposures within each strata satisfy the proportional hazards assumption. To determine the hazard of experiencing any NCD, a Cox model stratified by outcome type and matched set was fitted to allow the baseline hazard to vary by outcome type. Robust standard errors were calculated for this model to account for the within-patient dependency between failure times. ${ }^{33}$ In a secondary analysis, the incidence of heart failure, hypertensive disease, ischemic heart disease, cerebrovascular disease, other heart disease, COPD, and asthma was compared between patients with and without CP using Cox models stratified by matched set.

Initially, unadjusted Cox models were fitted before adjustment for smoking status, alcohol consumption, BMI, and mean yearly GP consultation rate by including these variables as predictor variables in the Cox model. We adjusted for consultation rate because people with CP may be more likely to have a higher consultation rate and a higher consultation rate may be associated with diagnosis of an NCD. Multiple imputation by chained equations was used to impute missing data for BMI from a linear regression model. The procedure was performed with the ice command in Stata (StataCorp, College Station, TX). To avoid bias in the analysis models, the imputation model included all predictor variables in the outcome model, matching variables, outcomes, and additional predictors of $\mathrm{BMI} .{ }^{34}$ In addition to the event indicator, we included the untransformed event or censoring time because it was found to be one of the best of several approaches when multiply imputing a single normal covariate..$^{35}$ Forty imputed datasets were generated. ${ }^{34}$ Boxplots of the observed and imputed data over the imputations were generated to identify discrepancies between the observed and imputed datasets. Estimates were combined with the use of the Rubin ${ }^{36}$ rules. 
Because the mechanism underlying missing records for smoking status and alcohol consumption in primary care data is likely to be missing not at random as opposed to missing at random, ${ }^{37,38}$ multiple imputation is not appropriate for these data. Missing data for smoking status are most likely pertaining to ex-smokers and nonsmokers, and missing data for alcohol consumption are most likely pertaining to current drinkers. ${ }^{37,38}$ Therefore, smoking status was dichotomized as current smokers and noncurrent smokers, with missing data assumed to relate to non-current smokers as proposed by Marston et al. ${ }^{37}$ Alcohol consumption was dichotomized as current drinkers and non-current drinkers with missing records assumed to pertain to current drinkers. Because this is potentially a strong assumption, we conducted sensitivity analyses to assess the impact of imputation of missing data on effect estimates and inference.

\section{Subgroup analysis}

People with ID have established risk factors for NCDs such as obesity, physical inactivity, unhealthy eating behaviors, and antipsychotic medication. ${ }^{39-42}$ Therefore, the association between CP and NCD may be explained by ID. Furthermore, people with $\mathrm{CP}$ and ID are more likely to have epilepsy and sensory impairment and to be nonambulatory compared to those with $\mathrm{CP}$ without ID. ${ }^{43}$ Therefore, ID may be considered a crude proxy for severity of CP or complexity of the individual's overall medical condition. We conducted a subgroup analysis to examine whether the association between CP and NCD was explained by presence of ID. Participants with ID were identified by at least 1 Read code for ID recorded during the study period. The primary analysis was then repeated stratified by ID status to compare the hazard of cancer, cardiovascular disease, type 2 diabetes mellitus, and respiratory disease between patients with $\mathrm{CP}$ and ID and their matched controls and between patients with $\mathrm{CP}$ without ID and their matched controls.

\section{Model checking and sensitivity analyses}

The validity of the assumption of proportional hazards was assessed by plotting scaled Schoenfeld residuals against time for all models and including an interaction term between time and each predictor variable in each model. Martingale residuals were plotted against BMI and mean yearly GP consultations to ensure that there was a linear association between BMI, GP consultations, and each outcome. Three sensitivity analyses were conducted: (1) missing data for smoking status, alcohol consumption, and BMI were excluded (complete case analysis); (2) missing data for smoking status were recategorized as current smokers, and missing data for alcohol consumption were recategorized as non-current drinker; and (3) records of BMI, smoking status, and alcohol intake taken before research-standard follow-up were excluded.

\section{Standard protocol approvals, registrations, and patient consents}

The CPRD has obtained research ethics approval from a National Research Ethics Service Committee for observational research using anonymized CPRD data. The protocol was approved by the Independent Scientific Advisory Committee for Medicines and Healthcare Products Regulatory Agency Database Research (protocol No. 16_077 R2A).

\section{Data availability}

As a result of CPRD data governance, data obtained from the CPRD are not available from the study authors. Applications to access data may be made to the CPRD at cprd.com.

\section{Results}

After exclusions, 1,705 patients with at least 1 record of $\mathrm{CP}$ who were at least 18 years old within the study period and research-standard follow-up were identified and matched to 5,115 patients without CP for age, sex, and practice. Characteristics of patients with and without CP at the start of follow-up are reported in table 1. Fifty-three percent of patients were male. The median age at the start of follow-up was 29 years. Underweight was more prevalent and overweight and obesity were less prevalent among patients with CP. A smaller proportion of patients with CP were current smokers or current drinkers. Median follow-up time for patients with CP ranged from 6.07 years (range 0.002-27.94 years) for cardiovascular disease to 7.15 years (range 0.04-27.94 years) for cancer. Median follow-up time for patients without CP ranged from 9.25 years (range 0.008-27.94 years) for cardiovascular disease to 10.91 years (range 0.05-28.01 years) for cancer.

There was evidence from unadjusted and adjusted analyses that the risk of any NCD was higher among patients with $\mathrm{CP}$ compared to patients without CP (table 2). Patients with CP had a $75 \%$ increased risk of any NCD (hazard ratio [HR 1.75 , 95\% confidence interval [CI] 1.58-1.94). Unadjusted HRs showed evidence that patients with $\mathrm{CP}$ had a higher risk of cardiovascular disease (HR 1.20, 95\% CI 1.03-1.40) and respiratory disease (HR 1.74, 95\% CI 1.47-2.06) than patients without CP. After adjustment for potential confounders, the association between CP and cardiovascular disease (HR 1.76, 95\% CI 1.48-2.11) and CP and respiratory disease (HR 2.61, 95\% CI 2.14-3.19) remained. There was no evidence of increased risk of cancer or type 2 diabetes mellitus from unadjusted or adjusted analyses.

For individual cardiovascular and respiratory diseases, unadjusted analyses showed evidence of association between CP and heart failure (HR 2.37, 95\% CI 1.47-3.84), cerebrovascular disease (HR 3.46, 95\% CI 2.14-5.60), and asthma (HR 1.31, 95\% CI 1.11-1.56) (table 3). Adjusted analyses also showed evidence of association between $\mathrm{CP}$ and heart failure (HR 2.62, 95\% CI 1.51-4.52), cerebrovascular disease (HR 5.53, 95\% CI 3.04-10.06), and asthma (HR 2.24, 95\% CI 1.82-2.76). There was no evidence from unadjusted analyses that CP was associated with hypertensive disease (HR 1.08, 95\% CI 0.91-1.28) or ischemic heart disease (HR 1.48, 95\% 
Table 1 Participant characteristics at start of follow-up

\begin{tabular}{|c|c|c|c|}
\hline Variable & $\begin{array}{l}\text { Patients with CP } \\
(n=1,705)\end{array}$ & $\begin{array}{l}\text { Patients without CP } \\
(n=5,115)\end{array}$ & $\begin{array}{l}\text { Total } \\
(n=6,820)\end{array}$ \\
\hline \multicolumn{4}{|l|}{ Sex } \\
\hline Male & $907(53.2)$ & $2,721(53.2)$ & $3,628(53.2)$ \\
\hline \multicolumn{4}{|l|}{ Age, y } \\
\hline Median (IQR), y & $29(20-42)$ & $29(20-42)$ & $29(20-42)$ \\
\hline$<30, \mathrm{n}(\%)$ & $877(51.4)$ & $2,631(51.4)$ & $3,508(51.4)$ \\
\hline $30-39$, n (\%) & $336(19.7)$ & $1,008(19.7)$ & $1,344(19.7)$ \\
\hline $40-49, n(\%)$ & $223(13.1)$ & $669(13.1)$ & $892(13.1)$ \\
\hline 50-59, n (\%) & $135(7.9)$ & 405 (7.9) & $540(7.9)$ \\
\hline$\geq 60, \mathrm{n}(\%)$ & $134(7.9)$ & $402(7.9)$ & $536(7.9)$ \\
\hline \multicolumn{4}{|l|}{ BMI, $\mathrm{kg} / \mathrm{m}^{2}$} \\
\hline Mean (SD) & $24.46(6.58)$ & $25.41(5.17)$ & $25.21(5.50)$ \\
\hline \multicolumn{4}{|l|}{$\begin{array}{l}\text { BMI categories, } \\
\mathrm{kg} / \mathrm{m}^{2}\end{array}$} \\
\hline$<18, \mathrm{n}(\%)$ & $109(6.4)$ & $75(1.5)$ & $184(2.7)$ \\
\hline $18-24, \mathrm{n}(\%)$ & $526(30.9)$ & $2,049(40.1)$ & $2,575(37.8)$ \\
\hline $25-29$, n (\%) & $232(13.6)$ & $1,210(23.7)$ & $1,442(21.1)$ \\
\hline$\geq 30, \mathrm{n}(\%)$ & $164(9.6)$ & $586(11.5)$ & $750(11.0)$ \\
\hline Missing, n (\%) & $674(39.5)$ & $1,195(23.4)$ & $1,869(27.4)$ \\
\hline \multicolumn{4}{|l|}{ Smoking status, n (\%) } \\
\hline Current smoker & $213(12.5)$ & $1,511(29.5)$ & $1,724(25.3)$ \\
\hline Ex-smoker & $65(3.8)$ & $424(8.3)$ & $489(7.2)$ \\
\hline Nonsmoker & $1,261(74.0)$ & $2,740(53.6)$ & $4,001(58.7)$ \\
\hline Missing & $166(9.7)$ & 440 (8.6) & $606(8.9)$ \\
\hline \multicolumn{4}{|l|}{ Alcohol consumption } \\
\hline Current drinker & $724(42.5)$ & $3,142(61.4)$ & $3,866(56.7)$ \\
\hline Ex-drinker & $15(0.9)$ & $40(0.8)$ & $55(0.8)$ \\
\hline Nondrinker & $527(30.9)$ & $640(12.5)$ & $1,167(17.1)$ \\
\hline Missing & $439(25.8)$ & $1,293(25.3)$ & $1,732(25.4)$ \\
\hline \multicolumn{4}{|l|}{ Practice region ${ }^{a}$} \\
\hline $\begin{array}{l}\text { North England and } \\
\text { Scotland }\end{array}$ & $473(27.7)$ & $1,419(27.7)$ & $1,892(27.7)$ \\
\hline Midlands and Wales & $603(35.4)$ & $1,809(35.4)$ & $2,412(35.4)$ \\
\hline South England & $587(34.4)$ & $1,761(34.4)$ & $2,348(34.4)$ \\
\hline Northern Ireland & $42(2.5)$ & $126(2.5)$ & $168(2.5)$ \\
\hline \multicolumn{4}{|l|}{$\begin{array}{l}\text { Mean yearly GP } \\
\text { consultations }\end{array}$} \\
\hline Median (IQR) & $6.03(2.44-12.01)$ & $2.32(0.82-5.05)$ & $2.89(1.03-6$ \\
\hline
\end{tabular}

Abbreviations: $\mathrm{BMI}=$ body mass index; $\mathrm{CP}=$ cerebral palsy; $\mathrm{GP}=$ general practitioner; $\mathrm{IQR}=$ interquartile range.

a North England and Scotland: Northeast England, Northwest England, Yorkshire, Scotland; Midlands. Wales: East Midlands, West Midlands, East of England, Wales. South England: Southwest England, South Central England, London, Southeast England. 
Table 2 Incidence rate and unadjusted and adjusted HRs for NCDs comparing patients with CP to patients without CP $(n=$ $6,820)$

\begin{tabular}{|c|c|c|c|c|c|c|c|}
\hline & Events, n (\%) & $\begin{array}{l}\text { Person-years, } \\
\times 1,000\end{array}$ & $\begin{array}{l}\text { Incidence, per 1,000 } \\
\text { person-y }\end{array}$ & $\begin{array}{l}\text { Unadjusted HR } \\
(95 \% \mathrm{Cl})\end{array}$ & $p$ Value & $\begin{array}{l}\text { Adjusted } \mathrm{HR}^{\mathrm{a}} \\
(95 \% \mathrm{CI})\end{array}$ & $p$ Value \\
\hline \multicolumn{8}{|l|}{ Cancer } \\
\hline $\mathrm{CP}$ & $15(0.88)$ & 14.5 & 1.03 & $0.99(0.55-1.78)$ & 0.980 & $1.35(0.71-2.56)$ & 0.362 \\
\hline Non-CP & $83(1.62)$ & 56.4 & 1.47 & 1 & & 1 & \\
\hline \multicolumn{8}{|c|}{$\begin{array}{l}\text { Type } 2 \\
\text { diabetes mellitus }\end{array}$} \\
\hline CP & $47(2.76)$ & 14.4 & 3.26 & $0.89(0.64-1.23)$ & 0.481 & $1.06(0.71-1.59)$ & 0.774 \\
\hline Non-CP & $214(4.18)$ & 55.4 & 3.86 & 1 & & 1 & \\
\hline \multicolumn{8}{|c|}{$\begin{array}{l}\text { All cardiova } \\
\text { scular disease }\end{array}$} \\
\hline $\mathrm{CP}$ & $248(14.6)$ & 13.1 & 19.0 & $1.20(1.03-1.40)$ & 0.021 & $1.76(1.48-2.11)$ & $<0.001$ \\
\hline Non-CP & 815 (15.9) & 50.5 & 16.1 & 1 & & 1 & \\
\hline \multicolumn{8}{|c|}{$\begin{array}{l}\text { Respiratory } \\
\text { disease }\end{array}$} \\
\hline $\mathrm{CP}$ & $215(12.6)$ & 14.3 & 15.0 & $1.74(1.47-2.06)$ & $<0.001$ & $2.61(2.14-3.19)$ & $<0.001$ \\
\hline Non-CP & $650(12.7)$ & 55.3 & 11.8 & 1 & & 1 & \\
\hline \multicolumn{8}{|l|}{ Any NCD } \\
\hline CP & - & - & - & $1.20(1.09-1.32)$ & $<0.001$ & $1.75(1.58-1.94)$ & $<0.001$ \\
\hline Non-CP & - & - & - & 1 & & 1 & \\
\hline
\end{tabular}

Abbreviations: $\mathrm{Cl}=$ confidence interval; $\mathrm{CP}=$ cerebral palsy; $\mathrm{HR}=$ hazard ratio; $\mathrm{NCD}=$ noncommunicable disease.

${ }^{a}$ Adjusted for smoking status, alcohol consumption, body mass index, and mean yearly general practitioner consultations.

CI 0.99-2.23). However, adjusted analyses showed evidence of increased risk of hypertensive disease (HR 1.64, 95\% CI 1.34-2.01) and ischemic heart disease (HR 2.32, 95\% CI 1.45-3.71) among people with CP.

\section{Subgroup analysis}

Twenty-one percent $(n=363)$ of patients with CP had a record of ID (table 4). Six percent $(n=24)$ of patients without $\mathrm{CP}$ had a record of ID; 10 were matched to patients with $\mathrm{CP}$ and ID, and 14 were matched to patients with CP without ID. We found evidence of increased risk of any NCD in patients with CP both with and without ID (table 5). Adjusted analyses showed evidence that patients with $\mathrm{CP}$ without ID had an increased risk of cardiovascular disease and respiratory disease, but not of cancer or type 2 diabetes mellitus (table 5). However, patients with CP and ID had increased risk of respiratory disease only (table 5).

\section{Sensitivity analyses}

Complete case analysis resulted in identical conclusions, with CIs including estimates obtained from the primary analysis (table 6). Similarly, sensitivity analyses after recategorization of missing data relating to smoking status and alcohol consumption and use of research-standard data only for smoking status, alcohol consumption, and BMI resulted in identical conclusions.

\section{Discussion}

We found evidence of an increased risk of cardiovascular disease and respiratory disease among adults with $\mathrm{CP}$ compared to adults without $\mathrm{CP}$ but no evidence of increased risk of cancer or type 2 diabetes mellitus. When we examined individual cardiovascular and respiratory diseases, we found an increased risk of heart failure, hypertensive disease, ischemic heart disease, cerebrovascular disease, and asthma among adults with CP.

Our results are broadly supportive of previous findings from a cross-sectional study conducted in the United States that found that the odds of hypertension, stroke, other heart disease, asthma, and emphysema were between 1.3 and 2.0 times higher among adults with CP compared to the general population. ${ }^{21}$ In accordance with our findings, there was no increased risk of diabetes mellitus among adults with $\mathrm{CP} .{ }^{21} \mathrm{~A}$ more recent cross-sectional study found that young adults with $\mathrm{CP}$ had higher odds of cardiometabolic morbidity compared to adults without CP (odds ratio 1.98, 95\% CI 
Table 3 Incidence rate and unadjusted and adjusted HRs for each cardiovascular and respiratory disease comparing patients with CP to patients without CP $(n=6,820)$

\begin{tabular}{|c|c|c|c|c|c|c|c|}
\hline & $\begin{array}{l}\text { Events, no. } \\
\text { (\%) }\end{array}$ & $\begin{array}{l}\text { Person-years, } \\
\times 1,000\end{array}$ & $\begin{array}{l}\text { Incidence, per 1,000 } \\
\text { person-y }\end{array}$ & $\begin{array}{l}\text { Unadjusted HR } \\
(95 \% \mathrm{CI})\end{array}$ & $\begin{array}{l}p \\
\text { Value }\end{array}$ & $\begin{array}{l}\text { Adjusted } \mathrm{HR}^{\mathrm{a}} \\
(95 \% \mathrm{CI})\end{array}$ & $\begin{array}{l}p \\
\text { Value }\end{array}$ \\
\hline \multicolumn{8}{|c|}{$\begin{array}{l}\text { Cardiovascular } \\
\text { disease }\end{array}$} \\
\hline \multicolumn{8}{|c|}{ Heart failure } \\
\hline $\mathrm{CP}$ & $30(1.76)$ & 14.5 & 2.07 & $2.37(1.47-3.84)$ & $<0.001$ & $2.62(1.51-4.52)$ & 0.001 \\
\hline Non-CP & $69(1.35)$ & 56.5 & 1.22 & 1 & & 1 & \\
\hline \multicolumn{8}{|c|}{$\begin{array}{l}\text { Hypertensive } \\
\text { disease }\end{array}$} \\
\hline $\mathrm{CP}$ & $187(10.97)$ & 13.4 & 13.98 & $1.08(0.91-1.28)$ & 0.398 & $1.64(1.34-2.01)$ & $<0.001$ \\
\hline Non-CP & $676(13.22)$ & 51.7 & 13.08 & 1 & & 1 & \\
\hline \multicolumn{8}{|c|}{$\begin{array}{l}\text { Ischemic heart } \\
\text { disease }\end{array}$} \\
\hline CP & $35(2.05)$ & 14.4 & 2.43 & $1.48(0.99-2.23)$ & 0.057 & $2.32(1.45-3.71)$ & $<0.001$ \\
\hline Non-CP & $108(2.11)$ & 55.9 & 1.93 & 1 & & 1 & \\
\hline \multicolumn{8}{|c|}{$\begin{array}{l}\text { Cerebrovascular } \\
\text { disease }\end{array}$} \\
\hline CP & $36(2.11)$ & 14.5 & 2.48 & $3.46(2.14-5.60)$ & $<0.001$ & $5.53(3.04-10.06)$ & $<0.001$ \\
\hline Non-CP & $76(1.49)$ & 56.5 & 1.34 & 1 & & 1 & \\
\hline \multicolumn{8}{|c|}{$\begin{array}{l}\text { Other heart } \\
\text { diseases }\end{array}$} \\
\hline $\mathrm{CP}$ & $25(1.47)$ & 14.5 & 1.72 & $0.84(0.54-1.32)$ & 0.457 & $1.07(0.66-1.71)$ & 0.790 \\
\hline Non-CP & $131(2.56)$ & 56.1 & 2.34 & 1 & & 1 & \\
\hline \multicolumn{8}{|c|}{ Respiratory disease } \\
\hline \multicolumn{8}{|l|}{ COPD } \\
\hline CP & $38(2.23)$ & 14.3 & 2.65 & $0.88(0.61-1.27)$ & 0.498 & $1.34(0.89-2.02)$ & 0.165 \\
\hline Non-CP & $171(3.34)$ & 55.3 & 3.09 & 1 & & 1 & \\
\hline \multicolumn{8}{|l|}{ Asthma } \\
\hline CP & $197(11.55)$ & 13.3 & 14.8 & $1.31(1.11-1.56)$ & 0.002 & $2.24(1.82-2.76)$ & $<0.001$ \\
\hline Non-CP & $534(10.44)$ & 52.2 & 10.2 & 1 & & 1 & \\
\hline
\end{tabular}

Abbreviations: $\mathrm{Cl}$ = confidence interval; $\mathrm{COPD}=$ chronic obstructive pulmonary disease; $\mathrm{CP}=$ cerebral palsy; $\mathrm{HR}=\mathrm{hazard}$ ratio.

${ }^{a}$ Adjusted for smoking status, alcohol consumption, body mass index, and mean yearly general practitioner consultations.

1.26-3.13), but not of pulmonary morbidity. ${ }^{22}$ However, the findings are not directly comparable because cardiometabolic morbidity was defined as the presence of at least one of several conditions, including type 2 diabetes mellitus, impaired glucose tolerance, and hyperlipidemia. Similarly, pulmonary morbidity was defined as a diagnosis of asthma, pulmonary embolism, or emphysema, so it is not possible to directly compare the results between studies. The HR for stroke in our study was higher than that observed in a cohort study in Taiwan, which found a 2-fold increased risk of stroke among people with $\mathrm{CP}$ compared to people without $\mathrm{CP} .^{23}$ Differences may have resulted because we controlled for smoking status, alcohol consumption, and BMI, which potentially confound the association between $\mathrm{CP}$ and stroke.

Although no study has compared the risk of cancer between adults with and without CP, 3 cohort studies have examined the risk of mortality due to cancer among adults with $\mathrm{CP}$ with inconsistent results. Two studies reported an increased risk of cancer-related mortality among adults with $\mathrm{CP}$ in California, ${ }^{18,19}$ and a third reported no increased risk among English adults with $\mathrm{CP} .{ }^{20}$ We similarly found no increased risk of cancer among adults with CP. Differences in results may be due to differences in the risk of cancer between $\mathrm{CP}$ 
Table 4 Patient characteristics at start of follow-up stratified by ID

\begin{tabular}{|c|c|c|c|c|}
\hline Variable & $\begin{array}{l}\text { Patients with CP } \\
\text { and ID }(n=363)\end{array}$ & $\begin{array}{l}\text { Patients without CP matched to } \\
\text { patients with CP and ID }(n=1,089)\end{array}$ & $\begin{array}{l}\text { Patients with CP } \\
\text { without ID }(n=1,342)\end{array}$ & $\begin{array}{l}\text { Patients without CP matched to } \\
\text { patients with CP without ID }(n=4,026)\end{array}$ \\
\hline \multicolumn{5}{|l|}{ Sex } \\
\hline Male & $204(56.2)$ & $612(56.2)$ & $703(52.4)$ & $2,109(52.4)$ \\
\hline \multicolumn{5}{|l|}{ Age, y } \\
\hline Median (IQR) & $29(21-40)$ & $29(21-40)$ & $29(20-43)$ & $29(20-43)$ \\
\hline$<30, \mathrm{n}(\%)$ & $186(51.2)$ & $558(51.2)$ & 691 (51.5) & 2073 (51.5) \\
\hline $30-39$, n (\%) & $84(23.1)$ & $252(23.1)$ & $252(18.8)$ & $756(18.8)$ \\
\hline $40-49$, n (\%) & $51(14.1)$ & $153(14.1)$ & $172(12.8)$ & $516(12.8)$ \\
\hline 50-59, n (\%) & $27(7.4)$ & $81(7.4)$ & $108(8.1)$ & $324(8.1)$ \\
\hline$\geq 60, n(\%)$ & $15(4.1)$ & $45(4.1)$ & 119 (8.9) & 357 (8.9) \\
\hline \multicolumn{5}{|l|}{ BMI, $\mathrm{kg} / \mathrm{m}^{2}$} \\
\hline Mean (SD) & $24.32(6.92)$ & $25.40(5.21)$ & $24.50(6.49)$ & $25.41(5.15)$ \\
\hline Range & $6.10-51.25$ & $16.06-54.60$ & $11.47-80.00$ & $5.9-63.71$ \\
\hline$<18, \mathrm{n}(\%)$ & $33(9.1)$ & $15(1.4)$ & $76(5.7)$ & $60(1.5)$ \\
\hline $18-24$, n (\%) & $102(28.1)$ & $459(42.2)$ & $424(31.6)$ & $1,590(39.5)$ \\
\hline 25-29, n (\%) & 39 (10.7) & $261(24.0)$ & $193(14.4)$ & 949 (23.6) \\
\hline$\geq 30, n(\%)$ & 45 (12.4) & $125(11.5)$ & 119 (8.9) & $461(11.5)$ \\
\hline Missing, n (\%) & 144 (39.7) & $229(21.0)$ & $530(39.5)$ & $966(24.0)$ \\
\hline \multicolumn{5}{|l|}{$\begin{array}{l}\text { Smoking status, } \\
\text { n (\%) }\end{array}$} \\
\hline $\begin{array}{l}\text { Current } \\
\text { smoker }\end{array}$ & $19(5.2)$ & $360(33.1)$ & $194(14.5)$ & $1,151(28.6)$ \\
\hline Ex-smoker & $5(1.4)$ & $96(8.8)$ & $60(4.5)$ & $328(9.3)$ \\
\hline Nonsmoker & $318(87.6)$ & $568(52.2)$ & $943(70.3)$ & $2,172(54.0)$ \\
\hline Missing & $21(5.8)$ & $65(6.0)$ & $145(10.8)$ & 375 (9.3) \\
\hline
\end{tabular}

\section{Alcohol}

consumption, $\mathbf{n}$

(\%)

\begin{tabular}{lllll}
\hline $\begin{array}{l}\text { Current } \\
\text { drinker }\end{array}$ & $123(33.9)$ & $699(64.2)$ & $601(44.8)$ & $2,443(60.7)$ \\
\hline Ex-drinker & $2(0.6)$ & $4(0.4)$ & $13(1.0)$ & $36(0.9)$ \\
\hline Nondrinker & $180(49.6)$ & $136(12.5)$ & $347(25.9)$ & $504(12.5)$ \\
\hline Missing & $58(16.0)$ & $250(23.0)$ & $381(28.4)$ & $1,043(25.9)$ \\
\hline $\begin{array}{l}\text { Mean yearly GP } \\
\text { consultations, } \mathbf{n}\end{array}$ & & & $5.40(2.20-10.70)$ & $2.28(0.78-5.03)$ \\
\hline Median (IQR) & $8.87(4.50-16.24)$ & $2.45(0.98-5.10)$ & & \\
\hline
\end{tabular}

Abbreviations: $\mathrm{BMI}=$ body mass index; $\mathrm{CP}=$ cerebral palsy; GP = general practitioner; ID = intellectual disability; IQR = interquartile range.

populations in the United States and United Kingdom. Alternatively, the discrepancy may have resulted because we defined cancer as the presence of cancer at 1 of 4 sites in our analysis (i.e., breast, colorectal, lung, or prostate). A cohort study in the United States found that adults with CP had a higher risk of death due to breast and colon cancer but not due to lung or prostate cancer, ${ }^{19}$ suggesting that the association between $\mathrm{CP}$ and cancer may be site specific. We were unable to examine risk by cancer site because we observed a relatively small number of cancer events in our sample. 
Table 5 Incidence rate and unadjusted and adjusted HRs for NCDs comparing patients with CP and ID to matched patients without CP $(n=1,452)$, and patients with CP without ID to matched patients without $C P(n=5,368)$

\begin{tabular}{|c|c|c|c|c|c|c|c|}
\hline & Events, n (\%) & Person-years, $\times 1,000$ & $\begin{array}{l}\text { Incidence, } \\
\text { per } 1,000 \\
\text { person-y }\end{array}$ & $\begin{array}{l}\text { Unadjusted } \\
\text { HR }(95 \% \mathrm{Cl})\end{array}$ & $p$ Value & Adjusted $\mathrm{HR}^{\mathrm{a}}(95 \% \mathrm{CI})$ & $p$ Value \\
\hline \multicolumn{8}{|l|}{ Cancer } \\
\hline CP and ID & $-{ }^{\mathrm{b}}$ & $-{ }^{\mathrm{b}}$ & $-{ }^{\mathrm{b}}$ & $0.86(0.18-4.13)$ & 0.848 & $4.75(0.33-69.3)$ & 0.254 \\
\hline Non-CP & $-{ }^{\mathrm{b}}$ & $-{ }^{\mathrm{b}}$ & $-{ }^{\mathrm{b}}$ & 1 & & 1 & \\
\hline CP without ID & $13(0.97)$ & 11.1 & 1.17 & $1.02(0.54-1.91)$ & 0.957 & $1.30(0.66-2.55)$ & 0.453 \\
\hline Non-CP & $71(1.8)$ & 44.4 & 1.60 & 1 & & 1 & \\
\hline \multicolumn{8}{|l|}{$\begin{array}{l}\text { Type } 2 \text { diabetes } \\
\text { mellitus }\end{array}$} \\
\hline CP and ID & $10(2.8)$ & 3.4 & 2.94 & $1.00(0.49-2.05)$ & 1.000 & $0.86(0.28-2.67)$ & 0.793 \\
\hline Non-CP & $34(3.1)$ & 12.0 & 2.85 & 1 & & 1 & \\
\hline CP without ID & $37(2.8)$ & 11.0 & 3.36 & $0.86(0.60-1.25)$ & 0.432 & $1.08(0.70-1.68)$ & 0.715 \\
\hline Non-CP & $180(4.5)$ & 43.5 & 4.14 & 1 & & 1 & \\
\hline \multicolumn{8}{|l|}{$\begin{array}{l}\text { Cardiovascular } \\
\text { disease }\end{array}$} \\
\hline CP and ID & $30(8.3)$ & 3.3 & 9.2 & $0.67(0.45-1.00)$ & 0.052 & $1.43(0.84-2.43)$ & 0.186 \\
\hline Non-CP & $145(13.3)$ & 11.1 & 13.0 & 1 & & 1 & \\
\hline CP without ID & $218(16.2)$ & 9.8 & 22.2 & $1.35(1.14-1.59)$ & $<0.001$ & $1.84(1.52-2.23)$ & $<0.001$ \\
\hline Non-CP & $670(16.6)$ & 39.4 & 17.0 & 1 & & 1 & \\
\hline \multicolumn{8}{|l|}{$\begin{array}{l}\text { Respiratory } \\
\text { disease }\end{array}$} \\
\hline CP and ID & $35(9.6)$ & 3.4 & 10.3 & $1.33(0.89-1.98)$ & 0.166 & $2.36(1.33-4.18)$ & 0.003 \\
\hline Non-CP & $131(12.0)$ & 12.0 & 10.9 & 1 & & 1 & \\
\hline CP without ID & $180(13.4)$ & 10.9 & 16.5 & $1.85(1.53-2.23)$ & $<0.001$ & $2.64(2.13-3.27)$ & $<0.001$ \\
\hline Non-CP & $519(12.9)$ & 43.3 & 12.0 & 1 & & 1 & \\
\hline \multicolumn{8}{|l|}{ Any NCD } \\
\hline CP and ID & - & - & - & $0.79(0.59-1.07)$ & 0.132 & $1.54(1.08-2.18)$ & 0.016 \\
\hline Non-CP & & & & 1 & & 1 & \\
\hline CP without ID & - & - & - & $1.30(1.18-1.44)$ & $<0.001$ & $1.79(1.61-1.99)$ & $<0.001$ \\
\hline Non-CP & & & & 1 & & 1 & \\
\hline
\end{tabular}

Abbreviations: $\mathrm{Cl}$ = confidence interval; $\mathrm{CP}=$ cerebral palsy; $\mathrm{HR}=$ hazard ratio; ID = intellectual disability; $\mathrm{NCD}=$ noncommunicable disease.

a Adjusted for smoking status, alcohol consumption, body mass index, and mean yearly general practitioner consultations.

${ }^{b}$ Data not reported because $<5$ events per cell.

While our results demonstrate an elevated risk of $\mathrm{NCD}$ among adults with CP, specifically cardiovascular disease and chronic respiratory disease, they do not elucidate mechanisms for this elevated risk. The prevalence of smoking and alcohol consumption was lower among adults with CP compared to adults without CP. Similarly, the prevalence of obesity was lower among adults with CP. However, it is possible that BMI as a metric lacks the sensitivity to detect high levels of body fat because people with $\mathrm{CP}$ have a lower proportion of lean body mass. ${ }^{44}$ Thus, BMI may be a poor indicator of metabolic risk factors such as hyperlipidemia in adults with $\mathrm{CP},{ }^{45,46}$ and poor cardiovascular outcomes may occur among people with $\mathrm{CP}$ at lower BMI cutoff points than those applied to the general population. Other potential factors driving the association between $\mathrm{CP}$ and increased rate of NCD may include physical inactivity and inadequate management of risk factors for NCD such as hyperlipidemia. While 1 study found that women with $\mathrm{CP}$ and ID were less likely to receive a mammogram compared to women with other causes of ID, no research has examined the management of NCD among 
Table 6 Incidence rate and unadjusted and adjusted HRs for NCDs using patients with complete data for smoking status, alcohol consumption, and BMI

\begin{tabular}{|c|c|c|c|c|c|c|}
\hline & \multicolumn{2}{|c|}{$\begin{array}{l}\text { Complete case analysis; all patients with } \\
\text { CP compared to matched patients } \\
\text { without CP }(n=4,463)\end{array}$} & \multicolumn{2}{|c|}{$\begin{array}{l}\text { Complete case analysis; patients with } \\
\text { CP and ID compared to matched } \\
\text { patients without CP } \\
(\mathrm{n}=991)\end{array}$} & \multicolumn{2}{|c|}{$\begin{array}{l}\text { Complete case analysis; patients with } \\
\text { CP without ID compared to matched } \\
\text { patients without CP } \\
(\mathrm{n}=3,472)\end{array}$} \\
\hline & $\begin{array}{l}\text { Adjusted } \mathrm{HR}^{\mathrm{a}} \\
(95 \% \mathrm{CI})\end{array}$ & $p$ Value & $\begin{array}{l}\text { Adjusted } \mathrm{HR}^{\mathrm{a}} \\
(95 \% \mathrm{CI})\end{array}$ & $p$ Value & $\begin{array}{l}\text { Adjusted } \mathrm{HR}^{\mathrm{a}} \\
(95 \% \mathrm{CI})\end{array}$ & $p$ Value \\
\hline Cancer & $1.68(0.77-3.66)$ & 0.194 & Not estimable & & $1.66(0.73-3.76)$ & 0.224 \\
\hline $\begin{array}{l}\text { Type } 2 \text { diabetes } \\
\text { mellitus }\end{array}$ & $1.22(0.74-2.00)$ & 0.434 & $0.51(0.13-2.09)$ & 0.352 & $1.39(0.81-2.40)$ & 0.237 \\
\hline $\begin{array}{l}\text { Cardiovascular } \\
\text { disease }\end{array}$ & $1.85(1.46-2.34)$ & $<0.001$ & $1.92(0.96-3.18)$ & 0.064 & $1.86(1.44-2.39)$ & $<0.001$ \\
\hline $\begin{array}{l}\text { Respiratory } \\
\text { disease }\end{array}$ & $2.49(1.92-3.24)$ & $<0.001$ & $2.18(1.07-4.45)$ & 0.033 & $2.62(1.97-3.47)$ & $<0.001$ \\
\hline Any NCD & $1.91(1.67-2.17)$ & $<0.001$ & $1.71(1.08-2.71)$ & 0.022 & $1.97(1.72-2.24)$ & $<0.001$ \\
\hline Heart failure & $3.38(1.44-7.91)$ & 0.005 & - & & - & \\
\hline $\begin{array}{l}\text { Hypertensive } \\
\text { disease }\end{array}$ & $1.94(1.50-2.52)$ & $<0.001$ & - & & - & \\
\hline $\begin{array}{l}\text { Ischemic heart } \\
\text { disease }\end{array}$ & $2.18(1.22-3.89)$ & 0.008 & - & & - & \\
\hline $\begin{array}{l}\text { Cerebrovascular } \\
\text { disease }\end{array}$ & $4.44(1.77-11.17)$ & 0.002 & - & & - & \\
\hline $\begin{array}{l}\text { Other heart } \\
\text { diseases }\end{array}$ & $1.32(0.70-2.51)$ & 0.391 & - & & - & \\
\hline COPD & $1.95(1.17-3.25)$ & 0.010 & - & & - & \\
\hline Asthma & $2.31(1.74-3.08)$ & $<0.001$ & - & & - & \\
\hline
\end{tabular}

Abbreviations: $\mathrm{BMI}=$ body mass index; $\mathrm{Cl}=$ confidence interval; $\mathrm{COPD}=$ chronic obstructive pulmonary disease; $\mathrm{CP}=\mathrm{cerebral}$ palsy; $\mathrm{HR}=$ hazard ratio; ID = intellectual disability; NCD = noncommunicable disease.

${ }^{a}$ Adjusted for smoking status, alcohol consumption, BMI, and mean yearly general practitioner consultations.

adults with $\mathrm{CP}$ without ID or specifically the management of cardiovascular disease in adults with $\mathrm{CP} .{ }^{13}$

$\mathrm{CP}$ is a heterogeneous condition in terms of severity of motor impairment and presence of associated conditions. It is possible that the association between $\mathrm{CP}$ and NCD differs according to severity of motor impairment, including ambulatory and feeding status, and the presence of associated conditions such as epilepsy and dysphagia. Although we did not examine the causes of increased risk of NCD among adults with $\mathrm{CP}$, we did examine whether ID explained it. ID may be considered a crude proxy for severity of $\mathrm{CP}$ in that it is strongly associated with the presence of epilepsy and severity of motor impairment; $83 \%$ of people with CP who are nonambulant and $78.6 \%$ of people with CP who have epilepsy have ID. ${ }^{43}$ This suggests that the majority of people with $\mathrm{CP}$ without ID in this analysis are likely to be ambulant and not to have epilepsy. However, the risk of NCD was still elevated in those without ID. We found that individuals with CP, both with and without ID, had increased risk of chronic respiratory disease, but the risk of cardiovascular disease was elevated only among those without ID. No previous study has examined whether the association between $\mathrm{CP}$ and $\mathrm{NCD}$ differs according to the presence of ID. However, a recent meta-analysis found that the pooled prevalence of type $2 \mathrm{di}$ abetes mellitus, cerebrovascular disease, and undefined cardiovascular disease was similar between people with ID and the general population. ${ }^{47}$ The prevalence of ischemic heart disease was found to be lower among people with $\mathrm{ID} .{ }^{47}$ Given that people with CP and ID are likely to have more severe motor impairment and therefore reduced life expectancy compared to those without ID, ${ }^{9}$ it is possible that they are more likely to die of acute conditions such as pneumonia before developing NCD. While there is clear evidence that adults with $\mathrm{CP}$ have increased risk of NCD, specifically cardiovascular disease and chronic respiratory disease, which is not wholly explained by ID, further research is needed to explore the etiology of NCD in CP.

The primary strength of our study is that it extends the current evidence base by leveraging a large sample of adults with $\mathrm{CP}$ to examine the incidence of a number of NCDs. ${ }^{17,22,23}$ The sample was obtained from a dataset that includes data from general practices across all regions of the United Kingdom 
and is largely representative of the UK population in terms of age and sex. In addition, we used physician diagnosis of $\mathrm{CP}$ and NCD, adjusted for several potential confounders, and assessed the robustness of our findings to a number of sensitivity analyses. There are also limitations to this study. We did not have data on physical activity and severity of motor impairment such as ambulatory status and feeding status. Because these are likely mediators of the association between $\mathrm{CP}$ and NCD, conditioning on them may induce bias. ${ }^{48}$ However, it is likely that the risk of NCD among the population of adults with CP differs according to severity of motor impairment. The inability to conduct stratified analysis according to motor function, based on Gross Motor Function Classification System level, for example, is an important limitation of this study that needs to be addressed in future research. Consistent with previous studies of primary care data, ${ }^{31,38}$ a substantial proportion of data were missing for smoking status, alcohol consumption, and BMI. Because data on smoking status and alcohol consumption in primary care datasets may be missing not at random and not missing at random, ${ }^{37,38}$ missing data were assumed to refer to nonsmokers and drinkers, respectively. While this is potentially an incorrect assumption to make, complete case analysis and recategorizing missing data to smokers and nondrinkers resulted in no difference in the conclusions of the study. Finally, because patients were followed up beyond the occurrence of a first event of any $\mathrm{NCD}$, assuming that the first event is an absorbing event potentially wastes information. We therefore chose to model the relationship between CP and each outcome separately because it was of interest to examine the association between $\mathrm{CP}$ and the first event of specific NCDs. However, although examining the association between CP and each NCD separately aids interpretation of the relationship between $\mathrm{CP}$ and $\mathrm{NCD}$ and provides more clinically relevant findings, the large number of analyses conducted potentially increased the risk of a type I error.

This study highlights the increased risk of potentially preventable NCDs among adults with CP. The results are largely consistent with previous evidence, which to date is primarily from US populations. Our results provide strong evidence that further research is needed to understand the causative mechanisms of this increased risk and to improve targeted interventions aimed at preventing NCDs among people with CP.

\section{Acknowledgment}

The authors acknowledge Dr. Gina McClelland for her assistance with identifying diagnoses.

\section{Study funding}

This study was supported by an Interdisciplinary Award from Brunel University London's Research Catalyst Fund.

\section{Disclosure}

The authors report no disclosures relevant to the manuscript. Go to Neurology.org/N for full disclosures.

\section{Publication history}

Received by Neurology February 25, 2019. Accepted in final form May 6, 2019.

Appendix Authors

\begin{tabular}{|c|c|c|c|}
\hline Name & Location & Role & Contribution \\
\hline $\begin{array}{l}\text { Jennifer M. } \\
\text { Ryan, PhD }\end{array}$ & $\begin{array}{l}\text { RCSI, Dublin, } \\
\text { Ireland }\end{array}$ & Author & $\begin{array}{l}\text { Study conception, design, } \\
\text { and interpretation; data } \\
\text { analysis; statistical } \\
\text { analysis; drafted the } \\
\text { manuscript }\end{array}$ \\
\hline $\begin{array}{l}\text { Mark D. } \\
\text { Peterson. } \\
\text { PhD }\end{array}$ & $\begin{array}{l}\text { University of } \\
\text { Michigan, Ann } \\
\text { Arbor }\end{array}$ & Author & $\begin{array}{l}\text { Study conception, design, } \\
\text { and interpretation; } \\
\text { revised the manuscript }\end{array}$ \\
\hline $\begin{array}{l}\text { Anthony } \\
\text { Matthews, } \\
\text { MSc }\end{array}$ & $\begin{array}{l}\text { London School of } \\
\text { Hygiene and } \\
\text { Tropical Medicine, } \\
\text { UK }\end{array}$ & Author & $\begin{array}{l}\text { Study design and } \\
\text { interpretation; data } \\
\text { management; revised the } \\
\text { manuscript }\end{array}$ \\
\hline $\begin{array}{l}\text { Nicola } \\
\text { Ryan, MB } \\
\text { BCh BAO }\end{array}$ & $\begin{array}{l}\text { Aberdeen Royal } \\
\text { Infirmary, } \\
\text { Scotland, UK }\end{array}$ & Author & $\begin{array}{l}\text { Study design and } \\
\text { interpretation; revised the } \\
\text { manuscript }\end{array}$ \\
\hline $\begin{array}{l}\text { Kimberley } \\
\text { J. Smith, } \\
\text { PhD }\end{array}$ & $\begin{array}{l}\text { University of } \\
\text { Surrey, UK }\end{array}$ & Author & $\begin{array}{l}\text { Study conception, design } \\
\text { and interpretation; } \\
\text { revised the manuscript }\end{array}$ \\
\hline $\begin{array}{l}\text { Neil E. } \\
\text { O'Connell, } \\
\text { PhD }\end{array}$ & $\begin{array}{l}\text { Brunel University } \\
\text { London, UK }\end{array}$ & Author & $\begin{array}{l}\text { Study conception, design, } \\
\text { and interpretation; } \\
\text { revised the manuscript }\end{array}$ \\
\hline $\begin{array}{l}\text { Silvia } \\
\text { Liverani, } \\
\text { PhD }\end{array}$ & $\begin{array}{l}\text { Queen Mary } \\
\text { University of } \\
\text { London, UK }\end{array}$ & Author & $\begin{array}{l}\text { Study conception, design, } \\
\text { and interpretation; } \\
\text { revised the manuscript }\end{array}$ \\
\hline $\begin{array}{l}\text { Nana } \\
\text { Anokye, } \\
\text { PhD }\end{array}$ & $\begin{array}{l}\text { Brunel University } \\
\text { London, UK }\end{array}$ & Author & $\begin{array}{l}\text { Study conception, design, } \\
\text { and interpretation; } \\
\text { revised the manuscript }\end{array}$ \\
\hline $\begin{array}{l}\text { Christina } \\
\text { Victor, PhD }\end{array}$ & $\begin{array}{l}\text { Brunel University } \\
\text { London, UK }\end{array}$ & Author & $\begin{array}{l}\text { Study conception, design, } \\
\text { and interpretation; } \\
\text { revised the manuscript }\end{array}$ \\
\hline $\begin{array}{l}\text { Elizabeth } \\
\text { Allen, PhD }\end{array}$ & $\begin{array}{l}\text { London School of } \\
\text { Hygiene and } \\
\text { Tropical Medicine, } \\
\text { UK }\end{array}$ & Author & $\begin{array}{l}\text { Study design and } \\
\text { interpretation; data } \\
\text { management and } \\
\text { analysis; revised the } \\
\text { manuscript }\end{array}$ \\
\hline
\end{tabular}

\section{References}

1. Rosenbaum P, Paneth N, Leviton A, et al. A report: the definition and classification of cerebral palsy April 2006. Dev Med Child Neurol Suppl 2007;109:8-14.

2. Colver A, Fairhurst C, Pharoah PO. Cerebral palsy. Lancet 2014;383:1240-1249.

3. Sellier E, Uldall P, Calado E, et al. Epilepsy and cerebral palsy: characteristics and trends in children born in 1976-1998. Eur J Paediatr Neurol 2012;16:48-55.

4. Andersen GL, Irgens LM, Haagaas I, Skranes JS, Meberg AE, Vik T. Cerebral palsy in Norway: prevalence, subtypes and severity. Eur J Paediatr Neurol 2008;12:4-13.

5. Reid SM, Modak MB, Berkowitz RG, Reddihough DS. A population-based study and systematic review of hearing loss in children with cerebral palsy. Dev Med Child Neurol 2011;53:1038-1045.

6. Brooks JC, Strauss DJ, Shavelle RM, Tran LM, Rosenbloom L, Wu YW. Recent trends in cerebral palsy survival, part I: period and cohort effects. Dev Med Child Neurol 2014;56:1059-1064.

7. DeGiorgio CM, Curtis A, Hertling D, Moseley BD. Sudden unexpected death in epilepsy: risk factors, biomarkers, and prevention. Acta Neurol Scand 2019;139:220-230.

8. Stankiewicz E, Ouellette-Kuntz H, McIsaac M, Shooshtari S, Balogh R. Patterns of mortality among adults with intellectual and developmental disabilities in Ontario. Can J Public Health 2018;109:866-872.

9. Brooks JC, Strauss DJ, Shavelle RM, Tran LM, Rosenbloom L, Wu YW. Recent trends in cerebral palsy survival, part II: individual survival prognosis. Dev Med Child Neurol 2014;56:1065-1071.

10. Smith KJ, Peterson MD, O'Connell NE, et al. Risk of depression and anxiety in adults with cerebral palsy. JAMA Neurol Epub 2018 Dec 28. 
11. Whitney DG, Hurvitz EA, Devlin MJ, et al. Age trajectories of musculoskeletal morbidities in adults with cerebral palsy. Bone 2018;114:285-291.

12. World Health Organization. Global Status Report on Noncommunicable Diseases 2014. Geneva: World Health Organization; 2014

13. Ryan JM, Allen E, Gormley J, Hurvitz EA, Peterson MD. The risk, burden, and management of non-communicable diseases among people with cerebral palsy: a scoping review. Dev Med Child Neurol 2018;60:753-764.

14. World Health Organization. Global Action Plan for the Prevention and Control of Noncommunicable Diseases 2013-2020. Geneva: World Health Organization; 2013.

15. Beaglehole R, Bonita R, Horton R, et al. Priority actions for the non-communicable disease crisis. Lancet 2011;377:1438-1447.

16. Bauman WA. The potential metabolic consequences of cerebral palsy: inferences from the general population and persons with spinal cord injury. Dev Med Child Neurol 2009;51(suppl 4):64-78.

17. Peterson MD, Gordon PM, Hurvitz EA. Chronic disease risk among adults with cerebral palsy: the role of premature sarcopoenia, obesity and sedentary behaviour. Obes Rev 2013;14:171-182.

18. Strauss D, Cable W, Shavelle R. Causes of excess mortality in cerebral palsy. Dev Med Child Neurol 1999;41:580-585.

19. Day SM, Brooks J, Strauss D, et al. Cancer mortality in cerebral palsy in California, 1988-2002. Int J Disabil Hum Dev 2008;7:427-434.

20. Ryan JM, Peterson MD, Ryan N, et al. Mortality due to cardiovascular disease, respiratory disease, and cancer in adults with cerebral palsy. Dev Med Child Neurol 2019;61:924-928.

21. Peterson MD, Ryan JM, Hurvitz EA, Mahmoudi E. Chronic conditions in adults with cerebral palsy. JAMA 2015;314:2303-2305.

22. Whitney DG, Hurvitz EA, Ryan JM, et al. Noncommunicable disease and multimorbidity in young adults with cerebral palsy. Clin Epidemiol 2018;10:511-519.

23. Wu CW, Huang SW, Lin JW, Liou TH, Chou LC, Lin HW. Risk of stroke among patients with cerebral palsy: a population-based cohort study. Dev Med Child Neurol 2017;59:52-56

24. Herrett E, Gallagher AM, Bhaskaran K, et al. Data resource profile: Clinical Practice Research Datalink (CPRD). Int J Epidemiol 2015;44:827-836.

25. Campbell JDD, Eaton SC, Gallagher AM, Williams TJ. Is the GPRD GOLD population comparable to the UK population. Pharmacoepidemiol Drug Saf 2013;22(suppl 1):280

26. Office for National Statistics. Cancer Registration Statistics. England: 2016. 2018. Available at: ons.gov.uk/peoplepopulationandcommunity/healthandsocialcare/conditionsanddiseases/bulletins/cancerregistrationstatisticsengland/final2016. Accessed April 18, 2019.

27. Nissen F, Morales DR, Mullerova H, Smeeth L, Douglas IJ, Quint JK. Validation of asthma recording in the Clinical Practice Research Datalink (CPRD). BMJ Open 2017;7:e17474.

28. Forbes HJ, Bhaskaran K, Thomas SL, Smeeth L, Clayton T, Langan SM. Quantification of risk factors for herpes zoster: population based case-control study. BMJ 2014;348:g2911.
29. Coding, Classification and Diagnosis of Diabetes. London: Royal College of General Practitioners; 2011.

30. Andersohn F, Schade R, Suissa S, Garbe E. Long-term use of antidepressants for depressive disorders and the risk of diabetes mellitus. Am J Psychiatry 2009;166:591-598.

31. Bhaskaran K, Forbes HJ, Douglas I, Leon DA, Smeeth L. Representativeness and optimal use of body mass index (BMI) in the UK Clinical Practice Research Datalink (CPRD). BMJ Open 2013;3:e003389.

32. Cummings P, McKnight B. Analysis of matched cohort data. Stata J 2004;4:274-281.

33. Cleves M. Analysis of multiple failure-time data with Stata. STB 2000;49:30-39.

34. White IR, Royston P, Wood AM. Multiple imputation using chained equations: issues and guidance for practice. Stat Med 2011;30:377-399.

35. White IR, Royston P. Imputing missing covariate values for the Cox model. Stat Med 2009;28:1982-1998.

36. Rubin DB. Multiple Imputation for Nonresponse in Surveys. New York: Wiley; 1987.

37. Marston L, Carpenter JR, Walters KR, et al. Smoker, ex-smoker or non-smoker? The validity of routinely recorded smoking status in UK primary care: a cross-sectional study. BMJ Open 2014;4:e004958.

38. Marston L, Carpenter JR, Walters KR, Morris RW, Nazareth I, Petersen I. Issues in multiple imputation of missing data for large general practice clinical databases. Pharmacoepidemiol Drug Saf 2010;19:618-626.

39. Hsieh K, Rimmer JH, Heller T. Obesity and associated factors in adults with in tellectual disability. J Intellect Disabil Res 2014;58:851-863.

40. Stancliffe RJ, Anderson LL. Factors associated with meeting physical activity guidelines by adults with intellectual and developmental disabilities. Res Dev Disabil 2017;62:1-14

41. Haupt DW, Newcomer JW. Hyperglycemia and antipsychotic medications. J Clin Psychiatry 2001;62(suppl 27):15-26.

42. Melville CA, Hamilton S, Hankey CR, Miller S, Boyle S. The prevalence and determinants of obesity in adults with intellectual disabilities. Obes Rev 2007;8 223-230.

43. Reid SM, Meehan EM, Arnup SJ, Reddihough DS. Intellectual disability in cerebral palsy: a population-based retrospective study. Dev Med Child Neurol 2018;60: 687-694.

44. Peterson MD, Zhang P, Haapala HJ, Wang SC, Hurvitz EA. Greater adipose tissue distribution and diminished spinal musculoskeletal density in adults with cerebral palsy. Arch Phys Med Rehabil 2015;96:1828-1833.

45. Ryan JM, Crowley VE, Hensey O, McGahey A, Gormley J. Waist circumference provides an indication of numerous cardiometabolic risk factors in adults with cerebral palsy. Arch Phys Med Rehabil 2014;95:1540-1546.

46. Peterson MD, Haapala HJ, Hurvitz EA. Predictors of cardiometabolic risk among adults with cerebral palsy. Arch Phys Med Rehabil 2012;93:816-821.

47. Dunkley AJ, Tyrer F, Spong R, et al. Screening for glucose intolerance and development of a lifestyle education programme for prevention of type 2 diabetes in a population with intellectual disabilities: the STOP Diabetes research project. Programme Grants Appl Res 2017;5.

48. Richiardi L, Bellocco R, Zugna D. Mediation analysis in epidemiology: methods, interpretation and bias. Int J Epidemiol 2013;42:1511-1519. 


\section{Neurology}

Noncommunicable disease among adults with cerebral palsy: A matched cohort study Jennifer M. Ryan, Mark D. Peterson, Anthony Matthews, et al.

Neurology 2019;93;e1385-e1396 Published Online before print August 28, 2019

DOI 10.1212/WNL.0000000000008199

This information is current as of August 28, 2019

Updated Information \&

Services

References

Subspecialty Collections

Permissions \& Licensing

Reprints including high resolution figures, can be found at: http://n.neurology.org/content/93/14/e1385.full

This article cites 41 articles, 4 of which you can access for free at: http://n.neurology.org/content/93/14/e1385.full\#ref-list-1

This article, along with others on similar topics, appears in the following collection(s):

All Cerebrovascular disease/Stroke

http://n.neurology.org/cgi/collection/all_cerebrovascular_disease_strok

e

Cardiac; see Cerebrovascular Disease/Cardiac

http://n.neurology.org/cgi/collection/cardiac_see_cerebrovascular_dise ase-cardiac

Cohort studies

http://n.neurology.org/cgi/collection/cohort_studies

Developmental disorders

http://n.neurology.org/cgi/collection/developmental_disorders

Information about reproducing this article in parts (figures,tables) or in its entirety can be found online at:

http://www.neurology.org/about/about_the_journal\#permissions

Information about ordering reprints can be found online:

http://n.neurology.org/subscribers/advertise

Neurology $\mathbb{B}$ is the official journal of the American Academy of Neurology. Published continuously since 1951, it is now a weekly with 48 issues per year. Copyright Copyright (C) 2019 The Author(s). Published by Wolters Kluwer Health, Inc. on behalf of the American Academy of Neurology.. All rights reserved. Print ISSN: 0028-3878. Online ISSN: 1526-632X.

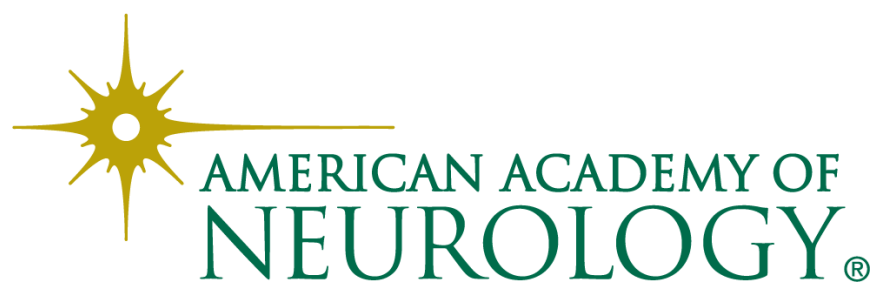

